\title{
Playability Evaluation using the Heuristic Evaluation of Playability Method in Warcraft 3 Reforged
}

\author{
Aldhiqo Yusron Mubarok*1, Umi Chotijah² \\ ${ }^{1,2}$ Program Studi Teknik Informatika, Universitas Muhammaddiyah Gresik \\ email: aldhiqo_170602@umg.ac.id*1,Umi.chotijah@umg.ac.id ${ }^{2}$
}

(Received: 30 Oktober 2021 / Accepted: 22 November 2021 / Published Online: 20 Desember 2021)

\begin{abstract}
Game is a digital activity that is very popular in the modern era, both among young and old. One game that is very popular with E-sports competition is Warcraft 3. However, in 2020 it immediately fell because Blizzard company has released a new version of those games which is called warcraft 3 reforged. The purpose of this study was to find out the reason this could happen by using the heuristic evaluation of playability method. With this method, you can find the scale of the problem in a game that will be released. The data used for this study uses the player persona as the source of the assessment that will be carried out in this game. The player persona is created by providing 10 respondents who will be required to perform and assess each task given according to the scenario codes. The benefits of this research can be used to analyse the readiness of games to be released to the market and to find out customer tastes in RTS (Real Time Strategy) type games. This assessment is based on the mean rating which will later be categorized as the level of problem in the running of the game. The results of this study indicate that the mean rating in this game is 2.91 or can be referred to as the Major Usability Problem with the highest value of percentage with the highest problem category found in the game usability with a percentage value of $41.7 \%$.
\end{abstract}

Keywords: Decision Support System, Game, Heuristic Evaluation of Playability, RTS, Warcraft 3 Reforged

\section{INTRODUCTION}

Video games are very interactive activities to be entertaining and challenging for the players (Lee, 2021). One of the most popular types of games is online games or multi-player games, there are many factors that multi-player games are often considered more adrenalinepumping and fun, this is because players do not compete with artificial intelligence opponents (Artificial Intelligence) but fight with other players. real people or what we call players, by fighting real players, players can experience things that are more unexpected and more fun (Jessie \& Saari, 2019).

Warcraft 3 is a game created by one of the well-known Blizzard developers where in 2003 - 2012 the Warcraft 3 game experienced a golden age and can be said to be the game with the most fans of its time. In 2020, Warcraft 3 finally experienced a reforged or overhaul in its design and gameplay which made this game an alpha or commonly called a game that is still developing (Naufal \& Yasin, 2021). Playability can be interpreted as a description of the overall quality of the game, which includes both usability and aspects of the game (Nguyen et al., 2018). Playability is one of the important factors because it can determine the success or failure of a video game in providing an interesting gaming experience for its players, so this game needs to be evaluated. In this study, the evaluation begins with creating a player persona, based on the results of direct interviews with 10 respondents who are players from the Warcraft 3 reforged game, to know the characteristics and categories of respondents when playing the Warcraft 3 reforged game. To be able to find out the playability aspect of the Warcraft 3 reforged game, an evaluation was carried out using the Heuristic Evaluation of Playability 
method which is an evaluation method devoted to evaluating games at the development stage (Ibrahim et al., 2019; Jantvongso \& Nuansomsri, 2020; Uggah et al., 2018). The research focuses on analysing and finding playability problems in the Warcraft 3 reforged game.

In conducting this research, the author has several references that are used as a reference in making this research. Research on cs go has been carried out to analyse user experience with the same method (Pandusarani et al., 2018). The research found several problems that the game players often complain about. These complaints are an indication of what new players, old players, and even pro players are complaining about. Unlike the cs go game, although it was found that there were many problems the game did not fall that much, while in warcraft the game immediately became a blasphemy of the world and went viral at the time of its release. In this study the author will focus on analysing why the game can be immediately hated after being released using the heuristic playability and player persona method. By using this method, the location of the problem will be clearly visible both in gameplay and story line. In contrast to previous research which focused from all points of view down to the proplayer, this research focuses on the general public or the public, both new players and old warcraft 3 players.

By using the player persona as a representative of each existing game player, general conclusions can be drawn which will later be used to analyse the cause and effect of the game (Angkasa \& Wijoyo, 2019). Games can also affect the psychology of the players depending on the genre being played, therefore in each game, there will be a warning that this game is for all ages or not (Prasetyo et al., 2020). Player psychology can also be influenced by the graphic aspect of the game (Warmelink et al., 2021). Graphics that look real often make players from the game plunge deeper into the game so that consciously or not it can affect the behaviour of players of all ages (Chang et al., 2019).

\section{METHOD}

The heuristic for Evaluating Playability is the result of the development of Heuristic Evaluation. Heuristic Evaluation is commonly used in the interface evaluation process (Aker et al., 2019; Huang, 2020; Yeratziotis \& Zaphiris, 2018; Zardari et al., 2021). Evaluation is used to measure the usability, efficiency, and effectiveness (Uska et al., 2020; Wirasasmiata \& Uska, 2019) of the interface based on ten usability evaluation heuristics that were studied by Jakob Nielsen in 1994, namely Nielsen's Usability heuristic. HEP is used in evaluating gameplay, game stories, mechanics, and usability (Ibrahim et al., 2020). HEP is a solution to the problem of Playability evaluation techniques. By focusing on how heuristics can be supported and violate (Desurvire et al., 2004).

Table 1. Main Menu

\begin{tabular}{cc}
\hline Skenario & Task \\
\hline T1-1 & Start warcraft 3 \\
T1-3 & login \\
T1-4 & Go to options menu \\
T1-5 & Go to settings then Sounds \\
T1-6 & Go to input \\
T1-7 & Go to video \\
T1-8 & Setting Gameplay \\
T1-9 & Do observation to all menus in Main Menu \\
T1-10 & Go to champaign \\
T1-11 & Tutorial mode \\
T1-12 & Find game Casual Mode \\
T1-13 & Find game Ranked Mode \\
\hline
\end{tabular}


In the research, we will make a scenario to test what and how the series of tasks will be carried out during the testing process. The task scenario will be the evaluator as a reference for processing the evaluation so that it is structured so that the evaluation process can run as expected and efficiently. The task scenario was created by analyzing the results of making player personal and analysing the Warcraft 3 reforged game. For table 1, the player persona will be assigned to follow the scenario according to the code. The scenario is used to determine the number of bugs in the main menu of the warcraft 3 refoged game. If all the tasks have been done, the player persona will give a value and what feedback they experienced.

Table 2. Game Story Mode

\begin{tabular}{cc}
\hline Skenario & Task \\
\hline T4-1 & click campaign on the menu \\
T4-2 & Choose main campaign or bonus champaign \\
T4-3 & Choose chapter story that you want \\
T4-4 & Organize your unit and base \\
T4-5 & Check the hot keys in game wether they work or not \\
T4-6 & Go to settings \\
T4-7 & Check whether the settings are in accordance, if there are changes, then reset \\
& it to your will. \\
T4-8 & Play the game \\
T4-9 & Observe and check the in-game menus \\
T4-10 & Observe and check all the fitures in game, then continue the game. \\
T4-11 & Give rating to player after the game ends. \\
T4-12 & Give evaluation to warcrafts 3 gameplay \\
\hline
\end{tabular}

In the table 2, the player persona will carry out testing tasks on the storyline of the game and the gameplay itself. By following the flow of the code scenario, the player persona will assess each activity assigned by the code. This serves to assess how many problems are found in the gameplay and the storyline.

Table 3. Game Versus Mode

\begin{tabular}{cc}
\hline Skenario & Task \\
T5-1 & Choose battle mode that you want \\
T5-2 & Choose race that you want \\
T5-3 & start game \\
T5-4 & Choose the building that ypu want to build first \\
T5-5 & Choose hero and unit that will be used \\
T5-6 & Go to setting \\
T5-7 & Check whether the settings are already good or not, if there aren't any \\
T5-8 & then continue the game. \\
T5-9 & Play the game \\
T5-10 & Observe and check all the menus, then continue the game \\
T5-11 & Observe and check all the fitures in game, then continue the game \\
T5-12 & Give rating to player after the game ends \\
\hline
\end{tabular}

The player persona will assess the custom mode game, in this assessment it will focus on detecting whether the game can be played with other players, either from the same region or different. Another assessment that can be made is whether this game can accommodate players according to the maximum player or whether the game will crash during the war (see table 3 ). 


\section{RESULT AND DISCUSSION Result}

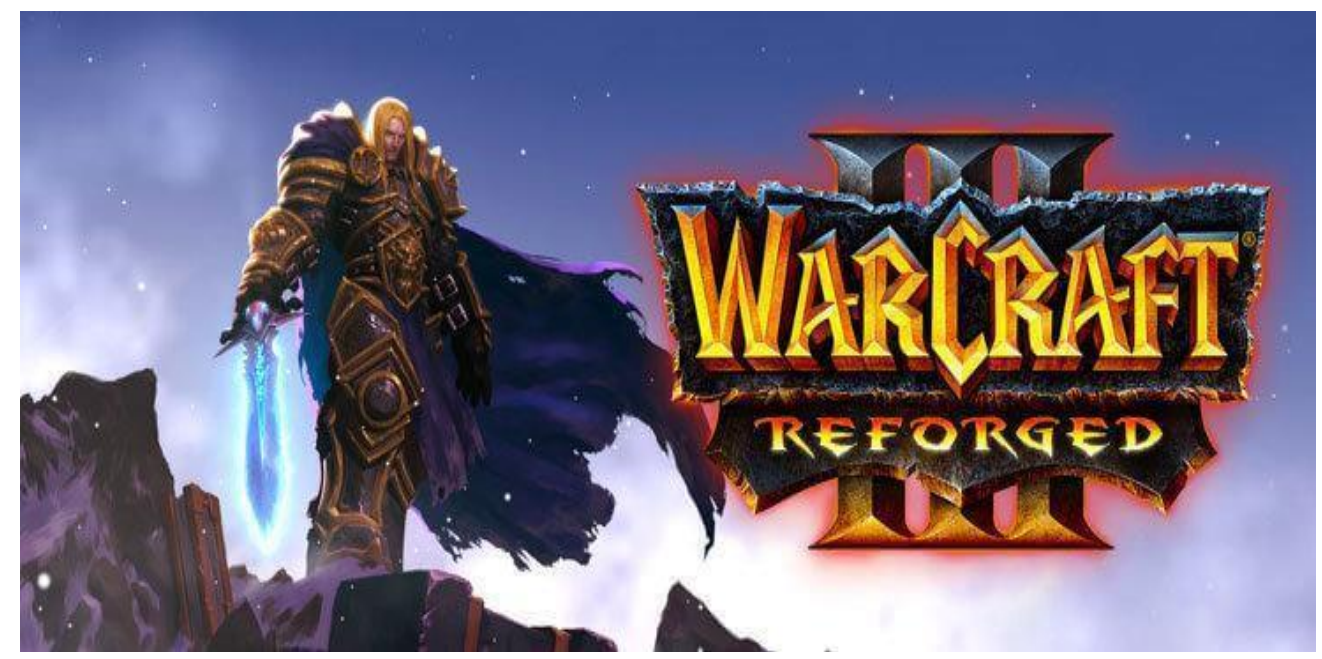

Figure 1. Warcraft 3 Reforged Game

The results obtained in this study are the number of problems in the Warcraft 3 game in the gameplay category as many as 19 problems. The problem is in the heuristic code quoted and taken in the book "game user research" (Drachen et al., 2018), GP2 is 2 problems, GP4 is 3 problems, GP6 is 1 problem, GP10 is 12 problems, and GP11 is 1 problem. The results of the Severity Ratings from these problems have the highest score on the Severity Ratings 3 scale which is at the Major level.

The problem of the game warcraft 3 reforged in the game usability category is 28 problems. There are heuristic code GU2 with 5 problems, GU3 with 5 problems, GU6 with 8 problems, GU7 with 2 problems, GU8 with 1 problem, GU9 with 4 problems, and GU11 with 3 problems. The results of the Severity Ratings from these problems are mostly with a Severity Rating scale of 2 which is at the Minor level.

The results and the number of problems found in the Warcraft 3 reforged game in the multi-player category were 10 problems in the multi-player category (see table 4 ). The problem lies in the MP1 heuristic code with 2 problems, MP4 with 3 problems, and MP9 with 5 problems. The results of the Severity Ratings of the 10 problems are the most with a Severity Rating scale of 3 which is at the Major level. These are the result of the research that we have done. Every tables has has a result of every problem that the game had.

Table 4. Number of Problems in Each Category

\begin{tabular}{ccc} 
Heuristic category & Number of problems & Percentage \\
\hline Gameplay & 19 & $28 \%$ \\
Game Usability & 28 & $41.7 \%$ \\
Multiplayer & 20 & $29.8 \%$ \\
Total & $\mathbf{6 7}$ & \\
\hline
\end{tabular}

In table 5 it is known that the mean rating is 2.11 in the gameplay category, which indicates that the problems in the gameplay category in the Warcraft 3 reforged game include the Major Usability Problem, meaning that the problems found in the Warcraft 3 reforged game 
cause several problems or disturbances during the game. players play in the game and have a priority level of problem fixing for that category it is very important to fix it immediately.

Table 5. Gameplay Category Result

\begin{tabular}{ccc}
\hline No & Severity Ratings & Number of problems \\
\hline $\mathbf{1}$ & 1 = Cosmetic & 2 \\
$\mathbf{2}$ & 2 = Minor & 3 \\
$\mathbf{3}$ & 3 = Major & 9 \\
$\mathbf{4}$ & 4 = Catastrophe & 5 \\
& Mean Rating & $\mathbf{2 . 1 1}$ \\
\hline
\end{tabular}

In table 6 the mean rating is 2.34 in the game usability category, which indicates that the problems in the game usability category include Minor Usability Problems, meaning that the potential for problems to occur will lead to the user interface, features, and functions to facilitate the user's game while playing. Warcraft 3 reforged, however, the priority level of problem fixing for this category can be said to be low.

Table 6. Game Usability Category Result

\begin{tabular}{ccc}
\hline No & Severity Ratings & Number of Problems \\
\hline $\mathbf{1}$ & 1 = Cosmetic & 5 \\
$\mathbf{2}$ & 2 = Minor & 12 \\
$\mathbf{3}$ & 3 = Major & 7 \\
$\mathbf{4}$ & 4 = Catastrophe & 4 \\
& Mean Rating & $\mathbf{2 . 3 4}$ \\
\hline
\end{tabular}

Tabel 7. Multiplayer category result

\begin{tabular}{ccc}
\hline No & Severity Ratings & Number of Problems \\
\hline $\mathbf{1}$ & 1 = Cosmetic & 5 \\
$\mathbf{2}$ & 2 = Minor & 6 \\
$\mathbf{3}$ & 3 = Major & 7 \\
$\mathbf{4}$ & 4 = Catastrophe & 2 \\
& Mean Rating & $\mathbf{2 . 8 5}$ \\
\hline
\end{tabular}

Tabel 8. Mean Rating for Game Warcraft 3 reforged

\begin{tabular}{rcc}
\hline No & Severity Ratings & Number of Problems \\
\hline $\mathbf{1}$ & 1 = Cosmetic & 12 \\
$\mathbf{2}$ & 2 = Minor & 21 \\
$\mathbf{3}$ & $3=$ Major & 23 \\
$\mathbf{4}$ & 4 = Catastrophe & 11 \\
& Means rating & $\mathbf{2 . 9 1}$ \\
\hline
\end{tabular}

Table 7 shows the mean rating of 2.85 in the multiplayer category, which indicates that the problems in the multi-player category include Minor Usability Problems, which means that the problems found in the reforged Warcraft 3 game have the potential to cause some disturbance in that aspect. The thing that should be done is to fix all aspects of the problems belonging to that category. 
In table 8 the mean rating result is 2.91 , which indicates that the problem in the overall game quality includes the usability and aspects of the warcraft 3 reforged game including the Major Usability Problem, meaning that the problems found can cause problems for players which impact players not being comfortable playing the game.

\section{Discussion}

The problems found in this game are 67, with details as follows, there are problems in the gameplay category as many as 20 problems with a percentage of $29.8 \%$, in the game usability category as many as 30 problems with a percentage of $44.7 \%$, and in the multi-player category as many as 18 problems or $26.8 \%$. The highest problem is in the game usability category as many as 30 or $44.7 \%$ of the total problems found. That way, an analysis of the problem will be carried out along with recommendations for improvement obtained from suggestions for improvement by the evaluator which will later be combined with theoretical references through books and other media related to the problem.

In each category, the mean rating results are found which indicate how severe the problem is in each category. Within assessment category, a scale of 1 to 4 are going to be used, namely, cosmetic, minor, major, and catastrophe. With the value given by the player persona in each category, the results of each category will be visible. In the gameplay category, we have, 2 cosmetic, 3 minor, 9 major, and 5 catastrophes. With these problems, the mean value of 2.11 was found which was categorized as a major usability problem. In the game usability category we have, 5 cosmetics, 12 minor, 7 major, and 4 catastrophes. With these problems, the mean value was found to be 2.34 which was categorized as a minor usability problem. In the multiplayer category, we have 5 cosmetic, 6 minor, 7 major, and 2 catastrophes. With these problems, the mean value was found to be 2.85 which was categorized as a major usability problem. After each category has been assessed, the game as a whole will be assessed by combining all existing problems, so that a severity rating scale for the Warcraft 3 reforged game will be found, which is 2.91 or major usability problem.

In previous studies (Angkasa \& Wijoyo, 2019), research using the heuristic playability method in the vainglory game, using the player persona as the basis for the assessment. This research uses 6 respondents as a database that will be used to create a player personas. In this study, we used 10 respondents to make the results analyzed more concrete. We also add evaluators who have experience in the game industry, which will definitely add to the results of our research to be more concrete.

\section{CONCLUSION}

The results of the Player Persona evaluation using the Heuristic Evaluation of Playability (HEP) method on the reforged Warcraft 3 game resulted in a mean rating of 2.91, overall, the problem was classified as a Major Usability Problem. This can potentially cause the player's interest in playing the game to be lost due to bugs. The result of the largest mean rating is the gameplay category, which is 2.52 , or it can be interpreted that the problem is classified as a Major Usability Problem. Problems in the gameplay category must be the core of improvement in the development of the reforged Warcraft 3 game because players will find it difficult to control the game. The problems with the most results are problems in the game usability category, this category represents the user interface, features, and controls in the game. The reforged Warcraft 3 game in Alpha version can be played well, but it is recommended to update the next patch to fix existing bugs and add some features

\section{REFERENCES}

Aker, Ç., Rızvanoğlu, K., \& Bostan, B. (2019). Methodological review of playability heuristics. In Contemporary Topics in Computer Graphics and Games (pp. 81-117). Peter 
Lang Publishing

Angkasa, M. N. R., \& Wijoyo, S. H. (2019). Evaluasi Playability Dengan Player Persona Menggunakan Metode Heuristic Evaluation of Playability (HEP) Pada Game Vainglory. Jurnal Pengembangan Teknologi Informasi Dan Ilmu Komputer, 3(7), 6790-6798.

Chang, A., Montalvo, L., \& Paz, F. (2019). Usability and Playability Heuristics for Augmented Reality Video Games in Smartphones. International Conference on Human-Computer Interaction, 19-29. https://doi.org/10.1007/978-3-030-23535-2_2

Desurvire, H., Caplan, M., \& Toth, J. A. (2004). Using heuristics to evaluate the playability of games. Using Heuristics to Evaluate the Playability of Games, 1509-1512.

Drachen, A., Mirza-Babaei, P., \& Nacke, L. (2018). Games User Research. In Games User Research. Oxford University

Press. https://doi.org/10.1093/oso/9780198794844.001.0001

Huang, Z. (2020). Usability of tourism websites: a case study of heuristic evaluation. New Review of Hypermedia and Multimedia, 26(1-2), 55-91.

Ibrahim, A., Alkhazaleh, H., Abdallah, N., Habli, M., \& Zeki, T. (2019). Playability Heuristics. GIS-Business, 14, 667-678. https://doi.org/10.26643/gis.v14i6.15027

Ibrahim, A., Mahfuri, M., Abdallah, N., Alkhazaleh, H., \& Zeki, T. (2020). Using Playability Heuristics to Evaluate Player Experience in Educational Video Games. Journal of Theoretical and Applied Information Technology, 98(23), 3632-3642.

Jantvongso, S., \& Nuansomsri, C. (2020). Heuristic Evaluation of "PaPaYa PokPok": Case Study of a Mobile Game. KKU Research Journal (Graduate Studies), 20(2), 21-32.

Jessie, D., \& Saari, D. (2019). Multiplayer Games (pp. 153-174). https://doi.org/10.1007/9783-030-35847-1_6

Lee, Y. (2021). The Generation Gap of Game and Game Generation. The Journal of Humanities and Social Sciences 15(51), 1537-1552. https://doi.org/10.22143/HSS21.12.4.109

Naufal, A., \& Yasin, M. (2021). Design of Checkers Game Using Alpha-Beta Pruning Algorithm. INTENSIF Jurnal Ilmiah Penelitian Dan Penerapan Teknologi Sistem Informasi, 5, 279-295. https://doi.org/10.29407/intensif.v5i2.15863

Nguyen, T., Wright, M., Wellman, M., \& Singh, S. (2017). Multistage Attack Graph Security Games: Heuristic Strategies, with Empirical Game-Theoretic Analysis. Security and Communication Networks, 1-28. https://doi.org/10.1155/2018/2864873

Pandusarani, G., Brata, A. H., \& Jonemaro, E. M. A. (2018). Analisis User Experience Pada Game CS:GO dengan Menggunakan Metode Cognitive Walkthrough dan Metode Heuristic Evaluation. Jurnal Pengembangan Teknologi Informasi Dan Ilmu Komputer, 2(3), 940-950.

Prasetyo, T., Bastian, A., \& Sifana, T. (2020). Game Edukasi Pengenalan Gangguan Psikologis Remaja Menggunakan Metode DGBL-ID. Jurnal Nasional Komputasi Dan Teknologi Informasi (JNKTI), 3, 121-131. https://doi.org/10.32672/jnkti.v3i2.2030

Uggah, L. L., Azaini, A., \& Adis, A. A. (2018). Evaluating South Korean Based Mobile Role Playing Games with Playability Heuristic Evaluation. International Journal of Engineering \& Technology, 7(3.18), 1-3.

Uska, M., Wirasasmita, R., Usuluddin, U., \& Arianti, B. (2020). Evaluation of RapidminerAplication in Data Mining Learning using PeRSIVA Model. Edumatic: Jurnal Pendidikan Informatika , 4(2), 164-171. https://doi.org/10.29408/edumatic.v4i2.2688

Warmelink, H., Elderen, J., \& Mayer, I. (2021). Game Design Elements (pp. 40-60). Routledge https://doi.org/10.4324/9780429316722-4

Wirasasmiata, R., \& Uska, M. (2019). Evaluation of E-Rapor Usability using Usability Testing Method. 6th International Conference on Educational Research and Innovation (ICERI 2018), 71-74. Yogyakarta, Indonesia: Atlantis Press. https://doi.org/10.2991/iceri- 
18.2019 .15

Yeratziotis, A., \& Zaphiris, P. (2018). A heuristic evaluation for deaf Web user experience (HE4DWUX). International Journal of Human-Computer Interaction, 34(3), 195-217.

Zardari, B. A., Hussain, Z., Arain, A. A., Rizvi, W. H., \& Vighio, M. S. (2021). QUEST elearning portal: Applying heuristic evaluation, usability testing and eye tracking. Universal Access in the Information Society, 20(3), 531-543. 